DOI 10.37882/2223-2982.2020.11.24 \title{
РЕПРЕЗЕНТАЦИЯ КОНЦЕПТА «ВИРУС» В ГАЗЕТНЫХ ТЕКСТАХ
}

\section{REPRESENTATION OF THE CONCEPT "VIRUS» IN NEWSPAPER TEXTS}

\section{E. Maletin}

Summary: The article examines the notion of concept, and also analyzes the main options for representing the concept of «virus» in newspaper texts of leading English-language publications, based on a sample of the texts that were analyzed. This concept is represented, both in connection with lexical means, and at the level of associations and in connection with other concepts such as «enemy», «struggle», «crisis».

Keywords: concept, virus, representation, crisis, social, political, economic differences, political leader, information strategies, information war.

\author{
Малетин Евгений Андреевич \\ Стариий преподаватель, Санкт-Петербургский \\ государственный университет \\ gtskeugen@yandex.ru
}

Аннотация: В статье рассмотрены понятие концепта, а также проанализированы основные варианты репрезентации концепта «вирус» В газетных текстах ведущих англоязычных изданий, на основании выборки изученных публикаций. Данный концепт репрезентуется, как во взаимосвязи с лексическими способами, так и на уровне ассоциаций и во взаимосвязи с другими концептами, такими как «враг», «борьба», «кризис».

Ключевые слова: концепт, вирус, репрезентация, кризис, социальные, политические, экономические различия, политический лидер, информационные стратегии, информационная война.

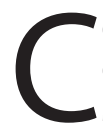

егодня популярность для современной лингвистики такого научного определения как «концепт» может сравняться только с разносторонностью его толкования.

Говоря об упомянутой единице понятийного аппарата, отметим, что вариативность дефиниций не стала поводом разногласий в среде исследователей, где царит единодушно принятая антропоцентрическая парадигма языкознания и когнитивно-прагматическая методология как основы формирования данного определения.

Дискуссии о мировоззренческих интенциях современного индивида зачастую происходят с употреблением данного термина как базис его репрезентации. Понятие становится объектом исследования передовых ученых, среди которых выделяется работа А.К. Киклевича «Динамическая лингвистика: между кодом и дискурсом». В труде профессор лингвистки изучает аспекты проблемного характера концепта как феномена с ярко выраженным атрибутом прагматической релевантности. Интересным видится заключение лингвиста, акцентирующее разнородность содержательного и функционального начала концепта [3]. В монографии концепты ранжируются, исходя из структуры культурного субъекта, на отдельные градации: от универсальных до присущих только определенной нации, региону, социальной или демографической группе, профессии, вероисповеданию, исторической эпохе [3].

В настоящее время как актуальный концепт заявил о себе номинатив «вирус», сферой функционирования которого является профессионально ориентированная среда. Лексема имеет несколько смыслов, и является полисемантической. Русский язык воспринял слово через два столетия от его возникновения в английском научном вокабулярии, где в 1728 г. лексема была использована для номинации возбудителей инфекционных патологий. В данном случае английские медики обсуждали передачу венерического заболевания, тогда как о еще не известных тогдашней науке вирусов в современном понимании, речь уже не шла.

Обратившись к такому авторитетному изданию как Новый словарь иностранных слов, в статье «Вирусы» к переводу с латыни virus - «яд» предложены такие смыслы:

1. Объекты, способные вызвать развитие инфекционной болезни у человека, домашней и дикой фауны и флоры, а также поражать бактерии и простейших;

2. Программный продукт, работа которого мешает цифровому устройству реализовать заданные функции, а также способный стереть банк данных с накопленной информацией [4].

Как видим, смыслы являются разно-отраслевыми, однако интегрированы на единой основе - вредоносном влиянии (для жизни на планете или для цифровой техники),

Изучив лексемы, построенные на основании указанного корня, упомянем слова: вирусный, антивирус, завирусованный, вируссодержащий, вирусность, противовирусный, вирусоподобный. Сегодня в публикациях СМИ актуальными являются предикатные конструкции, использующие номинатив «вирус» для обозначения опасности различного рода: ликвидация вируса, уникальный вирусный штамм, рост вируса, атака вирусов на организм, вирусологические исследования, поток вирусов. 
Нельзя не упомянуть о том, что корень «вирус» лег в основу конструкции, номинирующей актуальное пандемическое инфекционное заболевание COVID-2019: коронавирусная инфекция, коронавирусный госпиталь, помощь больным коронавирусом.

Кроме того, масс медиа используют слово «вирус» как профессионально маркированный концепт нередко метафорически, строя сравнения и фразеологизмы, формируя перифразы и вставляя в речь оборотыштампы: «Вирусный агент, гриппозный вирус, средство с противовирусным действием; вирусное заболевание, прервать чикл репликации вируса; поражение вирусом стяжательства; поражен вирусом сквернословия».

Наиболее актуальные статьи в 2020 году связаны с пандемией коронавируса, что дает возможность проанализировать немалое количество упоминаний понятия «вирус» и связанных с ним.

Рассмотрим, как концепт «вирус» представлен в текстах различных газетных изданий, в частности англоязычных The American Conservative, The Fox, The Washington Post, The New York Times и Financial Times.

Анализ выборки различных статей показал, что чаще всего концепт «вирус» представлен, как нечто живое, боевой, активный элемент, то, что способно разобщать, воевать, уничтожать. Человечество и государства в данном случае выступают как противники вируса, поэтому чаще всего «вирус» можно наблюдать в контексте таких понятий, как «борьба», «сражение», «противостояние», «битва», «спасение», «стратегии».

Например, это отражается, в текстах самих публикаций: "There is increasing confidence that the COVID-19 outbreak likely originated in a Wuhan laboratory, though not as a bioweapon but as part of China's attempt to demonstrate that its efforts to identify and combat viruses are equal to or greater than the capabilities of the United States..." [8].

А также в заголовках:

1. Mark Penn: In coronavirus fight, America needs a 60day plan to battle virus and save our economy [7].

2. Whose coronavirus strategy worked best? Scientists hunt most effective policies [10].

Таким образом, лексика, связанная с военными действиями, сражениями, разобщением, активно используется для того, чтобы сформировать представление о том, что вирус - это враг, убийца, разрушитель.

Также здесь стоит отметить тот факт, что в газетных текстах прослеживается идея о разобщении и разделении людей: "If we ever were One we are not now. Because we are for certain not all in this together as Governor Andrew
Cuomo said: "Everyone is subject to this virus. I don't care how smart, how rich, how powerful you think you are" [2].

Одновременно, здесь подчеркивается и мысль о том, что вирус - эта сила, для которой не имеет значения, что или кого разрушать, все люди для него едины, следовательно, такая репрезентация способствует тому, что люди начинают меньше задумываться о социальных, экономических, политических различиях, а концентрируются на страхе перед невидимым врагом, для борьбы с которым необходимо объединяться.

Наряду с этим концепт «вирус» сочетается с такими понятиями, как «кризис», «проверка», «испытание», «жертва». В этом смысле он выступает как активное действующее лицо, существует сам по себе, обладает физическими свойствами и способен совершать активные действия, приводящие к пагубным последствиям.

1. Американская газета New York Times в воскресенье, 24 мая, посвятила первую полосу жертвам коронавируса, опубликовав пофамильный список погибших в США. Печатная версия издания вышла под заголовком: “US deaths near 100,000 an incalculable loss", который сопровождается кратким некрологом [9].

2. China's health crisis is testing the entire global economic system, and placing unexpected and additional strain on the fragility of an extended boom. It's also $\underline{a}$ test of China's strength as a consumer-and the U.S.'s ability to step up as China lags [5].

Интересно наблюдение о том, что несмотря на то, что в СМИ активно фокусируются на борьбе с вирусом, в текстах достаточно часто находит свое отражение идея о том, что в текущей ситуации «вирус» - один из активных политических игроков на мировой арене наряду с государствами, правительствами, влиятельными политиками. Он представляется, как некий политический лидер, активно влияющий на обстановку на финансовых рынках, на международные отношениях, на экономическую и политическую ситуацию в конкретных странах, на разжигание торговых войн:

1. Sagging demand for crude oil, which has stumbled $16 \%$ in price since China identified the coronavirus, is prompting Saudi Arabia, the de facto leader of the Organization of the Petroleum Exporting Countries, to push other members to convene an emergency meeting, OPEC officials said [5].

2. Will the coronavirus outbreak derail the global economy? So how is the virus affecting economic activity within China? Most industries in China shut down over the two weeks around the lunar new year. The majority of factories were not expected to open again until this weekend and some have delayed opening until 14 February as a precaution, as tens of millions of people remained locked down in dozens of cities across the 
country [11].

3. Fears of global economic slowdown as virus follows trade war. China, and the world, were already burdened by tariffs. Now, some say the coronavirus could undermine fragile growth [6].

Одна из наиболее ярких репрезентаций заключается в том, что на сегодняшний день в условиях пандемии концепт «вирус» используется в качестве одного из наиболее эффективных средств в информационной войне между государствами, для создания конкретных образов и пропаганды различных идей.

The New York Times: "A Coronavirus Mystery Explained: Moscow Has 1,700 Extra Death. MOSCOW - Ever since the coronavirus took hold globally, researchers have been puzzled by Russia's mortality rate of only about 13 deaths per million, far below the world average of 36 in a country with an underfunded health system" [1].

Одновременно с публикацией The New York Times британская Financial Times опубликовала текст с еще более громким заголовком: "Russia's Covid death toll could be 70 per cent higher than official figure" [12].

Можно сделать вывод о том, что концепт «вирус» эксплуатируется государствами и лидерами этих государств в формировании определенных информационных стратегий, которые в свою очередь используется как инструмент для создания репутационного актива в информационных войнах.

Таким образом, нами были проанализированы статьи различных англоязычных изданий, в текстах публикаций которых встречается концепт «вирус». В качестве основных направлений репрезентации данного концепта нами были определены следующие:

- Вирус - враг, убийца, разрушитель.

- Вирус - кризис, страх, разобщение.

- Вирус - негласный политический игрок.

- Вирус - инструмент создания информационных стратегий.

Каждая из этих репрезентаций находит свое отражение в контексте текущей эпидемиологической и геополитической ситуации в мире и позволяет сделать вывод о том, что СМИ активно используют «вирус», как инструмент для формирования громких, привлекающих внимание заголовков, что способствует повышению заинтересованности и вовлеченности читателей, а также формированию определенных образов с целью влияния на общественное мнение и настроение.

\section{ЛИТЕРАТУРА}

1. A Coronavirus Mystery Explained: Moscow Has 1,700 Extra Deaths 11.05.2020 - [Электронный ресурc]. - URL: https://www.nytimes.com/2020/05/11/world/ europe/coronavirus-deaths-moscow.html

2. Rich and Healthy Vs. Poor and Dead 15.04.2020 // The American Conservative (США) [Электронный ресурc]. - URL: https://www.theamericanconservative.com/ articles/rich-and-healthy-vs-poor-and-dead-in-nyc/

3. Киклевич А.К. Динамическая лингвистика: между кодом и дискурсом. - Х., Изд-во «Гуманитарный центр», 2014. - 444 с.

4. Новый словарь иностранных слов / Сост. М. Ситникова - Изд. 4-е., стереотип. - Ростов н/Д.: Феникс, 2010. - 299 с.

5. Coronavirus Closes China to the World, Straining Global Economy. 03.02.2020 // The Wall Street Journal - [Электронный ресурc]. - URL: https://www.wsj.com/ articles/coronavirus-closes-china-to-the-world-straining-global-economy-11580689793?mod=hp_lead_pos1

6. Fears of global economic slowdown as virus follows trade war. // The Guardian - [Электронный ресурc]. - URL: https://www.theguardian.com/business/2020/ feb/01/fears-global-economic-slowdown-coronavirus-follows-trade-war

7. Mark Penn: In coronavirus fight, America needs a 60-day plan to battle virus and save our economy. 21.03.2020 // Foxnews. - [Электронный ресурс]. - URL: https://www.foxnews.com/opinion/mark-penn-in-coronavirus-fight-america-needs-a-60-day-plan-to-battle-virus-and-save-our-economy

8. Sources believe coronavirus outbreak originated in Wuhan lab as part of China's efforts to compete with US. 15.04.2020 // Foхnеws. - [Электронный ресурс]. URL: https://www.foxnews.com/politics/coronavirus-wuhan-lab-china-compete-us-sources

9. US deaths near 100,000 an incalculable loss. 27.05.2020 // The New York Times - [Электронный ресурc]. - URL: https://www.nytimes.com/ interactive/2020/05/24/us/us-coronavirus-deaths-100000.html

10. Whose coronavirus strategy worked best? Scientists hunt most effective policies 27.04 .2020 // Nature. - [Электронный pecypc]. - URL: https://www.nature.com/ articles/d41586-020-01248-1

11. Will the coronavirus outbreak derail the global economy? //The Guardian - [Электронный ресурc]. - URL: https://www.theguardian.com/news/2020/feb/10/ will-the-coronavirus-outbreak-derail-the-global-economy

12. Russia's Covid death toll could be 70 per cent higher than official figure 11.05.2020 // Financial Times - [Электронный ресурc]. - URL: https://www.ft.com/ content/77cd2cba-b0e2-4022-a265-e0a9a7930bda

( ) Малетин Евгений Андреевич (gtskeugen@yandex.ru).

Журнал «Современная наука: актуальные проблемы теории и практики» 